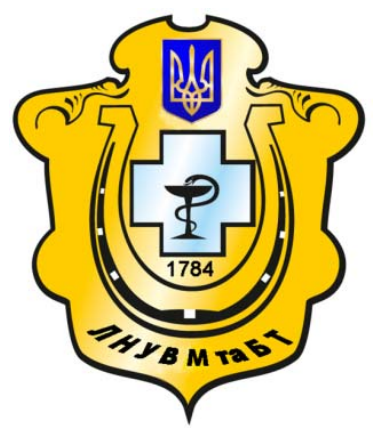

Науковий вісник Львівського національного університету ветеринарної медицини та біотехнологій імені С.3. Гжицького

Scientific Messenger of Lviv National University of Veterinary Medicine and Biotechnologies named after S.Z. Gzhytskyj

doi:10.15421/nvlvet7004

ISSN 2413-5550 print

ISSN 2518-1327 online

http://nvlvet.com.ua/

УДК 619:616.61-008.6:636.8

\title{
Гістологічна діагностика хронічної ниркової недостатності в котів
}

\author{
Б.В. Борисевич ${ }^{1}$, В. Свириденко ${ }^{1}$, В.В. Гуніч ${ }^{2}$ \\ gunichvika@ukr.net \\ ${ }^{1}$ Національний університет біоресурсів і природокористування Украӥни, \\ вул. Героїв Оборони, 15, м. Київ, 03041, Україна; \\ ${ }^{2}$ Одеський державний аграрний університет, \\ провулок Олександра Матросова, 6, м. Одеса, 65000, Украӥна
}

\begin{abstract}
Мета дослідження - встановити критерії гістологічної діагностики хронічної ниркової недостатності в котів. Прижиттєвий діагноз на хронічну ниркову недостатність встановлювали комплексно з урахуванням анамнезу, клінічних ознак і результатів лабораторних досліджень сироватки крові та сечі. Для проведення гістологічних досліджень було використано 29 трупів котів різних порід і віку, які загинули від хронічної ниркової недостатності. Парафінові зрізи товщиною 7 10 мкм з різних ділянок нирок котів фарбували гематоксиліном Караці та еозином.

Встановлено, що при проведенні гістологічних досліджень у нирках котів, які загинули внаслідок хронічної ниркової недостатності, характерним є строкатість мікроскопічних змін. Характерним для хронічної ниркової недостатності котів є комплекс мікроскопічних змін, який включає: 1) розширення та переповнення кров'ю капілярів частини клубочків; 2) сладж-феномен у капілярах частини клубочків; 3) відсутність крові в капілярах частини клубочків; 4) підвищену кількість фільтрату в порожнині капсули Боумена-Шумлянського; 5) потовщення (в частині випадків півмісящеподібне) парієтального листка капсули Боумена-Шумлянського за рахунок гіпертрофії та гіперплазї ї̈ клітин у частини ниркових тілець; 6) склероз клубочків частини ниркових тілець і тотальний склероз частини ниркових тілець; 7) утворення мікрокіст, головним чином у кірковій речовині. Інші мікроскопічні зміни в різних тварин варіюють.

Ключові слова: коти, патологія нирок, хронічна ниркова недостатність, діагностика, гістологічна діагностика, нирки, ниркові тільия, гломерулонефрит, канальиі нирок, мікроскопічні зміни, дистрофічні зміни.
\end{abstract}

\section{Гистологическая диагностика хронической почечной недостаточности у котов}

\author{
Б.В. Борисевич ${ }^{1}$, В. Свириденко ${ }^{1}$, В.В. Гунич ${ }^{2}$ \\ gunichvika@ukr.net \\ ${ }^{1}$ Национальный университет биоресурсов и природопользования Украины, \\ ул. Героев Обороны, 15, г. Киев, 03041, Украина; \\ ${ }^{2}$ Одесский государственный аграрный университет, \\ переулок Александра Матросова, 6, м. Одеса, 65000, Украина
}

\begin{abstract}
Цель работы - установить критерии гистологической диагностики хронической почечной недостаточности у котов. Прижизненный диагноз на хроническую почечную недостаточность ставили комплексно с учетом анамнеза, клинических признаков и результатов лабораторных исследований крови и мочи. Для гистологических исследований было использовано 29 трупов котов разных пород и возраста, павших от хронической почечной недостаточности. Парафиновые срезы толщиной 7 - 10 мкм из разных участков почек окрашивали гематоксилином Караци и эозином.

Установлено, что при проведении гистологических исследований в почках котов, павших от хронической почечной недостаточности, характерным есть пестрота микроскопических изменений. Характерным для хронической почечной недо-
\end{abstract}

Citation:

Borysevich, B.V., Sviridenko, V., Hunich, V.V. (2016). Histological diagnostics of the chronic kidney insufficiency in cats. Scientific Messenger LNUVMBT named after S.Z. Gzhytskyj, 18, 3(70), 17-20. 
статочности котов является комплекс изменений, который включает: 1) расширение и переполнение кровью капилляров части клубочков; 2) сладж-феномен в капиллярах части клубочков; 3) отсутствие крови в капиллярах части клубочков; 4) повышенное количество фильтрата в полости капсуль Боумена-Шумлянского; 5) утолщение (в части случаев месяце подобное) париетального листка капсуль Боумена-Шумлянского за счет гипертрофии и гиперплазии его клеток у части почечных телеч; 6) склероз клубочков части почечных телеч и тотальный некроз части почечных телеч; 7) образование микрокист, главным образом в корковом веществе. Другие микроскопические изменения у разных животных варьируют.

Ключевые слова: коты, патология почек, хроническая почечная недостаточность, диагностика, гистологическая диагностика, почки, почечные тельца, гломерулонефрит, канальцы почек микроскопические изменения, дистрофические изменения.

\title{
Histological diagnostics of the chronic kidney insufficiency in cats
}

\author{
B.V. Borysevich ${ }^{1}$, V. Sviridenko ${ }^{1}$, V.V. Hunich ${ }^{2}$ \\ gunichvika@ukr.net \\ ${ }^{1}$ National university of life and environmental sciences of Ukraine, \\ Heroes of Defense Str., 15, Kyiv, 03041, Ukraine; \\ ${ }^{2}$ Odessa state agrarian university, \\ Alexander Matrosov, 6, Odesa, 65000, Ukraine
}

\begin{abstract}
The objective of the study is to set the criteria of histological diagnosis of chronic renal insufficiency in cats. Lifetime diagnosis of chronic renal failure in a complex was set in complex, basing on anamnesis, clinical signs and laboratory results of blood and urine. For histological studies 29 cats corpses of different breeds and ages were used, who died from chronic kidney failure. Paraffin sections of $7-10 \mathrm{~mm}$ thickness from the different segments of kidney were stained with Carazzi's hematoxylin and eosin.

It was established that during the histological studies in the kidney of cats who died from chronic kidney failure the microscopic changes diversity is characteristic. A characteristic feature of chronic kidney failure cats is complex of changes, which includes: 1) expand and overflow of blood capillaries of the glomeruli; 2) sludge-phenomenon in the capillaries of the glomerulus; 3) lack of blood in the capillaries of the glomerulus; 4) an increased amount of leachate in the cavity of Boumen-Shumlyanskiy capsule; 5) thickening (in some cases crescent-like) of parietal layer of Boumen-Shumlyanskiy capsule due to the hypertrophy and hyperplasia of its cells in the part of kidney cells; 6) glomerular sclerosis of the renal corpuscles and total necrosis of the renal corpuscles; 7) microcysts formation, mainly in the cortex. Other microscopic changes in different animals vary.
\end{abstract}

Key words: cats, renal failure, chronic renal failure, diagnosis, histological diagnosis, kidney, renal corpuscles, glomerulonephritis, renal tubules, microscopic changes, degenerative changes.

\section{Вступ}

Ниркова недостатність (НН) реєструється в тварин багатьох видів: домашніх, продуктивних і лабораторних (Fenoglio et al., 2008; Kocjumbas et al., 2009). У різних популяціях котів усіх країн світу серед іншої патології нирок найчастіше виявляють ниркову недостатність, яка в старих тварин є переважаючою причиною смерті чи евтаназії (Chakrabarti et al., 2012).

Хронічна ниркова недостатність (ХНH) - клінічна знахідка, частота виявлення якої зростає з віком котів: за різними даними вона уражає від третини до більше ніж $60 \%$ старих котів. Завдяки складності і багатоплановості ХНH, ïi діагностика і лікування також складні і багатопланові залежно від конкретного прояву цієї патології (Ross and Osborne, 2006).

Патоморфологічна діагностика НН має значення не тільки в випадку загибелі тварин, але й відіграє значну роль у прижиттєвій діагностиці цієї патології (Kausman and Kitching, 2007; Vlizlo et al., 2009), оскільки однотипні зміни біохімічних показників сироватки крові та сечі можуть відображати різні за своїм характером патологічні процеси (Lokes and Kravchenko, 2005; Yabuki et al., 2010). Встановлення характеру морфологічних змін у нирках вкрай необхідне не тільки з точки зору діагностики, але й для адекватного лікування НН і більш точного прогнозу щодо подальшого розвитку цієї патології (Asano et al.,
2008). В той же час патоморфологічні зміни при ХНН вивчені недостатньо повно.

Мета дослідження - встановити критерії гістологічної діагностики ХНН у котів. Для досягнення мети були поставлені наступні завдання: 1) з'ясувати мікроскопічні зміни в ниркових тільцях котів за ХНH; 2) з'ясувати мікроскопічні зміни в канальцях нирок котів за ХНH; 3) з'ясувати мікроскопічні зміни в стромі нирок котів за ХНH.

\section{Матеріал і методи досліджень}

Діагноз на ХНН встановлювали комплексно з урахуванням анамнезу, клінічних ознак і результатів лабораторних досліджень сироватки крові та сечі. Для проведення гістологічних досліджень було використано 29 трупів котів різних порід і віку, які загинули від ХНH, а також 5 контрольних котів різних порід і віку, які були евтаназовані в притулку для тварин (Бородянський р-н, Київська обл.).

Патологоанатомічний розтин трупів усіх котів проводили методом часткової евісцерації в загальноприйнятій послідовності (Zon et al., 2009). Для гістологічних досліджень відбирали шматочки 3 різних ділянок нирок (з кожної нирки не менше 5 шматочків). Відібрані шматочки фіксували в 10\% водному нейтральному розчині формаліну та після зневоднення в етанолах зростаючої концентрації через хлороформ заливали в парафін. Зрізи товщиною 7 - 10 мкм 
одержували за допомогою санного мікротому. Для виявлення мікроскопічної будови нирок проводили фарбування зрізів гематоксиліном Караці та еозином. Для диференціації гідропічної та жирової дистрофій на заморожуючому мікротомі виготовляли заморожені зрізи товщиною 20 мкм, які для виявлення ліпідів зафарбовували розчином Судану III (Goral's'kyj et al., 2005). Одержані гістопрепарати вивчали під мікроскопом Olympus CX-41 при збільшеннях 50 - 1500 х. Фотографування препаратів здійснювали за допомогою мікроскопу Olympus $\mathrm{CX}-41$ та фотокамери Olympus C-7250.

\section{Результати та їх обговорення}

При проведенні гістологічних досліджень нирок котів, які загинули внаслідок ХНН, нами було виявлено два типи мікроскопічних змін.

Перший тип мікроскопічних змін відповідав першому типу макроскопічних змін. При цьому мікроскопічні зміни в одній і тій самій нирці були різноманітними, внаслідок чого орган при малих збільшеннях мікроскопу мав строкатий вигляд. Строкатість мікроскопічних змін була зумовлена їх різними характером і ступенем виразності в різних нефронах, у першу чергу в канальцях нирок. При хронічній нирковій недостатності виявлялися розширені канальці з переважно збереженим епітелієм, розширені канальці 3 переважно зруйнованим епітелієм і звужені канальці.

Мікроскопічні зміни в ниркових тільцях також були різноманітні, що відображало різні стадії розвитку в них патологічного процесу. Це дало нам змогу встановити морфогенез змін у нирках котів при хронічній нирковій недостатності. Процес починався з серозного екстракапілярного гломерулонефриту. Капіляри клубочків ниркових тілець на цій стадії розвитку патологічного процесу були розширені. В одних ниркових тільцях вони були порожніми, а в інших - містили клітини крові. При цьому еритроцити в просвіті переважної більшості капілярів клубочків були склеєні (сладж-феномен). Також виявляли зернисту та гідропічну дистрофію мезангіоцитів і подоцитів. Руйнування останніх свідчило про значне порушення фільтраційного бар'єру ниркових тілець.

Проте класичний екстракапілярний серозний гломерулонефрит у жодному з випадків нами встановлений не був, оскільки вже на цій стадії розвитку патології ниркових тілець в них починали виявлятися й інші, не типові для цього гломерулонефриту мікроскопічні зміни. Так, нами було зареєстровано гіпертрофію клітин простого плоского епітелію парієтального листка капсули Боумена-Шумлянського, яка в багатьох випадках супроводжувалась ще й гіперплазією її клітин. Це призводило до досить виразного потовщення парієтального листка капсули.

3 розвитком процесу відбувались набряк мезангіуму та часткове руйнування клубочку й гіпертрофованого парієтального листка капсули БоуменаШумлянського. Надалі відбувалось повна дезорганізація клубочка з руйнуванням більшої його частини. В багатьох випадках це супроводжувалось зернистою дистрофією епітеліальних клітин парієтального лист- ка капсули Боумена-Шумлянського. Дезорганізація й руйнування клубочків у відносно невеликої частини ниркових тілець $(18,7 \pm 5,4 \%$ від усіх ниркових тілець) супроводжувалась парціальним некрозом клубочка. В частині ниркових тілець потовщення парієтального листка капсули Боумена-Шумлянського було нерівномірним, внаслідок чого вона ставала схожою на півмісяць. У місці потовщення парієтального листка капсули Боумена-Шумлянського її простий плоский епітелій перетворювався на багатошаровий плоский епітелій. У частині ниркових тілець реєструвався склероз клубочків, який надалі переходив у склероз усього ниркового тільця.

Мікроскопічні зміни в звивистих канальцях були тісно пов'язані 3 характером мікроскопічних змін у нирковому тільці, з якого починався кожний конкретний нефрон. У нефронів, ниркове тільце яких у порожнині капсули Боумена-Шумлянського містило значну кількість рідини, звивисті канальці були виразно розширені. В них переважала гідропічна дистрофія епітеліальних клітин 3 частковим плазмолізисом, рідко вона проявлялася в вигляді балонної дистрофії.

Також слід зазначити, що клітини щільної плями проксимального звивистого канальця (одного 3 компонентів юкстагломерулярного апарату, який відіграє важливу роль в системі ренін-ангіотензинальдостерон, через яку опосередковано відбувається регуляція об'єму й тиску крові) перебували в стані зернистої чи гідропічної дистрофії, або ж на різних стадіях руйнування. Зміни клітин щільної плями, разом із змінами екстрагломерулярних мезангіоцитів, свідчать про значні порушення в продукуванні реніну, оскільки зменшення кількості структурних елементів, які виробляють в організмі ту чи іншу субстанцію, призводить до зменшення кількості продукованої субстанції. Крім того, зміни екстрагломерулярних мезангіоцитів свідчать про порушення продукування еритропоетину, який вони секретують.

У нефронів, ниркове тільце яких у порожнині капсули Боумена-Шумлянського містило дуже мало рідини, або ж у яких реєструвались склероз клубочка чи склероз всього ниркового тільця, мікроскопічні зміни в звивистих канальцях мали кардинально інший характер. Як проксимальні, так і дистальні звивисті канальці на більшості їх ділянок були виразно звужені, а на окремих ділянках - розширені. В просвіті частини цих канальців виявлявся білковий детрит. Місцями в такий детрит відкладалися солі кальцію. Значна частина ділянок звивистих канальців руйнувалася, а на їх місці розросталася волокниста сполучна тканина.

Сукупність цих мікроскопічних змін давала загальну картину кіркової речовини нирки, в якій виявлялися змінені ниркові тільця, змінені звивисті канальці, мікрокісти різних розмірів та значні за розмірами ділянки склерозу.

У 67,4\% котів, які загинули внаслідок хронічної ниркової недостатності, при гістологічному дослідженні нирок також виявлявся вогнищевий інтерстиційний лімфоїдоцитарний нефрит. В таких вогнищах крім скупчення в інтерстиції органу лімфоцитів також 
реєстрували набряк та відносно незначну кількість моноцитів.

У мозковій речовині між канальцями реєструвалось розростання волокнистої сполучної тканини. Більша частина канальців була виразно звужена. Лише на окремих ділянках реєструвалось вогнищеве розширення прямих канальців, а місцями утворювались мікрокісти невеликих розмірів.

Переважна більшість вен строми була розширена й переповнена клітинами крові. Еритроцити в просвіті вен були склеєні між собою (сладж-феномен). Стінки вен у більшості випадків були досить виразно набряклі, а гладкі м'язові клітини їх медії перебували в стані зернистої дистрофії. В частини вен реєструвалось руйнування клітин їх ендотелію.

В просвіті артерій і артеріол клітини крові зазвичай були відсутні. Частина артеріол була звужена. При цьому їх ендотеліальні клітини випиналися в просвіт судини. В більшості артерій і артеріол реєструвалось руйнування їх ендотеліоцитів, при якому частково зруйновані клітини частково чи повністю відділялися в просвіт кровоносних судин цього типу. Гладкі м'язові клітини середньої оболонки артерій і артеріол перебували в стані зернистої дистрофії.

\section{Висновки}

1. При проведенні гістологічних досліджень у нирках котів, які загинули внаслідок хронічної ниркової недостатності, характерним є строкатість мікроскопічних змін.

2. Характерним для хронічної ниркової недостатності котів $\epsilon$ комплекс мікроскопічних змін, який включає: 1) розширення та переповнення кров'ю капілярів частини клубочків; 2) сладж-феномен у капілярах частини клубочків; 3) відсутність крові в капілярах частини клубочків; 4) підвищену кількість фільтрату в порожнині капсули БоуменаШумлянського; 5) потовщення (в частині випадків півмісяцеподібне) парієтального листка капсули Боумена-Шумлянського за рахунок гіпертрофії та гіперплазії ії клітин у частини ниркових тілець; 6) склероз клубочків частини ниркових тілець і тотальний склероз частини ниркових тілець; 7) утворення мікрокіст, головним чином у кірковій речовині. Інші мікроскопічні зміни в різних тварин варіюють.

Перспективи подальших досліджень. У подальшому необхідно з'ясувати мікроскопічні зміни в інших органах котів за ХНH.

\section{Бібліографічні посилання}

Vlizlo, V.V. Maksymovych, I.A., Nicpon', J. (2009). Zastosuvannja biopsii' $\mathrm{u}$ diagnostyci hvorob nyrok $\mathrm{u}$ tvary. Veterynarna medycyna Ukrai'ny. 1, 16-17 (in Ukrainian).

Goral's'kyj, L.P., Homych, V.T., Konons'kyj, O.I. (2005). Osnovy gistologichnoi' tehniky i morfofunkcional'ni metody doslidzhennja $\mathrm{u}$ normi ta pry patologii'. Zhytomyr: Polissja (in Ukrainian).

Zon, G.A., Skrypka, M.V., Ivanivs'ka L.B. (2009). Patologoanatomichnyj roztyn tvaryn. Donec'k: PP Glazunov R.O. (in Ukrainian).

Kocjumbas, I.Ja., Shhebentovs'ka, O.M., Rudyk, G.V. (2009). Kliniko-anatomichna harakterystyka i gistologichni zminy $\mathrm{v}$ organah imunnoi' systemy, pechinci, nyrkah porosjat za hronichnogo $\mathrm{T}-2$ toksykozu ta vplyvu rozchyniv natriju gipohlorytu. Veterynarna medycyna Ukrai'ny. 4, 20-22 (in Ukrainian).

Lokes, P.I., Kravchenko, S.O. (2005). Morfologichni zminy nyrok pry polikistozi u kishok. Visnyk Poltav. derzh. agrar. akad. Poltava. 2, 68-70 (in Ukrainian).

Asano, T., Tsukamoto, A., Ohno, K. et al. (2008). Membranoproliferative glomerulonephritis in a young cat. J. Vet. Med. Sci. 70, 12, 1373-1375.

Chakrabarti, S., Syme, H.M., Elliott, J. (2012). Clinicopathological variables predicting progression of azotemia in cats with chronic kidney disease. J. Vet. Intern. 26(2), 275-281.

Fenoglio, C.A., Grosso, A., Petrillo, G. et al. (2008). Histochemical approach to the evaluation of the in vivo cytotoxicity of the nitrobutadienes (1E,3E)-1,4bis(1-naphthyl)-2,3-dinitro-1,3-butadiene and methyl (2Z,4E)-2-methylsulfanyl-5-(1-naphthyl)-4nitro-2,4-pentadienoate in mice liver and kidney. Anticancer Res. 28(2), 7, 813-823.

Kausman, J.Y., Kitching, A.R. (2007). A new approach to idiopathic nephrotic syndrome. J. Am. Soc. Nephrol. 18(10), 2621-2622.

Ross, S., Osborne, C. (2006). Clinical progression of early chronic renal failure and implications for management. In: Consultations in Feline Internal Medicine (Ed. J. August). St. Louis O: Elsevier. 389.

Yabuki, A., Mitani, S., Fujiki, M. et al. (2010). Comparative study of chronic kidney disease in dogs and cats: induction of myofibroblasts. Res. Vet. Sci. 88(2), 294-299.

Стаття надійшла до редакиії 5.09.2016 